\title{
FOULING ASSEMBLAGES ASSOCIATED WITH ESTUARINE ARTIFICIAL REEFS IN NEW SOUTH WALES, AUSTRALIA*
}

\author{
Rob Mckenzie ${ }^{1 * *}$, Michael Lowry ${ }^{2}$, Heath Folpp ${ }^{l}$ and Marcus Gregson ${ }^{1}$ \\ ${ }^{1}$ NSW Department of Primary Industries (DPI) (Research Division) \\ Cronulla Fisheries Research Centre of Excellence
}

(PO Box 21 Cronulla 2230, Australia)

${ }^{2}$ NSW Department of Primary Industries (DPI) - Research Division (Port Stephens Research Centre Locked Bag 1 Nelson Bay NSW 2315, Australia)

**Corresponding author: Rob.McKenzie@industry.nsw.gov.au

\begin{abstract}
A B S T R A C T
Previous studies examining the dynamics of succession on artificial reefs have predominantly focussed on fish communities and largely ignored the role of fouling assemblages in explaining the patterns of community structure associated with artificial reefs. The objective of this study was to record the development of epibiotic assemblages on three "design specific" (Reef Ball ${ }^{\circledR}$ ) estuarine artificial reefs systems located in Lake Macquarie, Botany Bay and St Georges Basin in New South Wales, Australia. Recruitment to the artificial reefs was relatively rapid with the majority of taxa identified over the two-year study period observed within the first year post-deployment. The artificial reefs in Lake Macquarie and St Georges Basin were characterised by low diversity with four and nine taxa recorded respectively in contrast to the sixteen taxa observed on the Botany Bay reefs. Results indicated no significant differences in percentage cover of taxa among reefs in either St Georges Basin or Lake Macquarie. In contrast, comparisons between individual Botany Bay reefs identified significant differences in the percentage cover of species between artificial reefs. Analysis of assemblage structure with reef age indicated discrete patterns among estuaries with an overall reduction in the percentage cover of filamentous turfing algae (FTA) identified for all reef systems with an increase in reef age. Variations in environmental and physical conditions (turbidity, water flow, wave action and proximity to naturally occurring reef) may have contributed to the observed differences in fouling assemblages between estuaries and between artificial reefs within Botany Bay.
\end{abstract}

\section{RESUMO}

Estudos prévios que examinaram a dinâmica de sucessão em recifes artificiais foram focalizados nas comunidades de peixes, e sempre ignoraram o papel exercido pelos organismos incrustantes sobre a estruturação das comunidades associadas aos recifes artificiais. $\mathrm{O}$ presente estudo tem por objetivo registrar o desenvolvimento das assembléias epibióticas em três sistemas de recifes artificiais estuarinos com desenho específico (Reef Ball ${ }^{\circledR}$ ) localizados em Macquarie Lake, Botany Bay e Bacia de St Georges em New South Wales, Australia. O recrutamento nos recifes artificiais foi relativamente rápido e a maioria dos táxons identificados durante o período dos dois anos de estudo já pode ser observada no primeiro ano. Os recifes de Macquarie Lake e da Bacia de St Georges foram caracterizados por baixa diversidade, sendo registrado o número máximo de seis táxons; em contraste, nos recifes de Botany Bay foram observados dezesseis taxa. Os resultados indicaram que não houve diferença significativa na porcentagem de cobertura dos grupos taxonômicos, tanto na Bacia de St Georges quanto em Macquarie Lake. Por sua vez, as porcentagens de cobertura das espécies nos recifes de Botany Bay mostraram diferenças significativas dentro do complexo recifal. A análise da estrutura das assembléias, quando se considera a idade do recife, indicou a ocorrência de padrões discretos entre os estuários, havendo em geral uma redução da porcentagem de cobertura das algas filamentosas formadoras de tufos (AFT) com o aumento da idade recifal. As diferenças nas condições ambientais e físicas (turbidez, fluxo de água, ação das ondas e proximidade do recife natural) existentes entre estuários e recifes artificiais, podem ter contribuído para as variações observadas nas assembléias incrustantes em Botany Bay.

Descriptors: Artificial reef, Fouling, Epibenthos, Succession, Estuaries.

Descritores: Recifes artificiais, Incrustação, Epibentos, Sucessão, Estuários.

(*) Paper presented at the $9^{\text {th }}$ CARAH - International Conference on Artificial Reefs and Related Aquatic Habitats on 8-13 November, Curitiba, PR, Brazil. 


\section{INTRODUCTION}

The history of Australia's artificial reefs has been well-documented (POLLARD; MATTHEWS, 1985; POLLARD, 1989; BRANDEN et al., 1994; COUTIN, 2001) and reflects a more general global pattern with initial deployments characterised by the extensive use of "materials of opportunity" including car tyres and scuttled ships. The dubious environmental quality of early artificial reef construction materials, lack of pre-established objectives combined with a non-existent or ineffective monitoring approach limited the capacity of researchers and managers to assess the role of artificial reefs within a broader fisheries management framework (COUTIN, 2001). More stringent environmental controls combined with improvements in the construction and design of artificial reefs has resulted in a shift away from "materials of opportunity" to an increase in the deployment of purpose built or "design-specific" artificial structures (SHERMAN et al., 1999; BAINE, 2001; SUTTON; BUSHNELL, 2007; SU et al., 2008).

Developments in artificial reef design have been accompanied by more sophisticated experimental design and monitoring approaches (SEAMAN, 2000). These programs however, have typically been driven by fisheries enhancement objectives with the majority of studies focussed on aspects of fisheries ecology whilst largely ignoring the role of epiflora and epifauna (SEAMAN JR et al., 1989; SVANE; PETERSEN, 2001; CHAPMAN; CLYNICK, 2006). More recently, leaders in the field have repeatedly emphasised the need for a more multi-disciplinary approach to the evaluation of artificial reef habitats (BUTLER; CONNOLLY, 1996; CARR; HIXON, 1997; PITCHER; SEAMAN JR, 2000; SEAMAN JR; JENSEN, 2000; BRICKHILL et al., 2005) with particular emphasis on a better understanding of the role of fouling assemblages in artificial reef community development (SVANE; PETERSEN, 2001).

Studies of epibenthic communities associated with subtidal artificial structures in New South Wales (NSW) estuaries have been limited to assessments of non design-specific structures including marina seawalls and wharves (GLASBY, 1999; GLASBY; CONNELL, 1999; CHAPMAN; CLYNICK, 2006; CLYNICK et al., 2007). The results of these studies have established that benthic assemblages on hard reef surfaces (natural or artificial) are strongly influenced by a wide range of environmental variables which include water depth (MOURA et al., 2007; RULE; SMITH, 2007), orientation in relation to prevailing currents (BAYNES; SZMANT, 1989; ABELSON, 1994), orientation of surfaces (GLASBY; CONNELL,
2001), complexity of surfaces and structure (KNOTT et al., 2004; EDWARDS; SMITH, 2005; MOURA et al., 2007) and are linked to the establishment of migratory and stationary fish assemblages (ABURTOOROPEZA; BALART, 2001; EDWARDS; SMITH, 2005; CHAPMAN; CLYNICK, 2006; CLYNICK et al., 2007; REDMAN ; SZEDLMAYER, 2009).

In 2002, commercial fishing was removed from popular recreational fishing areas in NSW resulting in the creation of 30 recreational fishing havens (RFHs). From 2002-2007 a total of 18 artificial reefs constructed from design-specific concrete Reef Ball $^{\circledR}$ modules were deployed in three RFHs (Lake Macquarie, Botany Bay and St Georges Basin) in order to further enhance recreational fishing opportunities. An understanding of the succession of fouling assemblages associated with design specific reef materials and the associated fish community is of particular importance for artificial reef programs designed to enhance fishing opportunities. Therefore, the aim of this study is to: (a) describe the succession of epibenthic assemblages associated with Reef Ball ${ }^{\circledR}$ estuarine artificial reef complexes and (b) examine variations in fouling communities within and among estuaries.

\section{Material and Methods}

\section{Study Sites}

The largest of the estuaries is Lake Macquarie ( $\left.33^{\circ} 09^{\prime} \mathrm{S} 151^{\circ} 66^{\prime} \mathrm{E}\right)$ with a total area of 114 square kilometres $\left(\mathrm{km}^{2}\right)$. St Georges Basin $\left(35^{\circ} 18^{\prime} \mathrm{S}\right.$ $\left.150^{\circ} 59 \mathrm{E}\right)$ and Botany Bay $\left(33^{\circ} 00^{\prime} \mathrm{S} 151^{\circ} 23^{\prime} \mathrm{E}\right)$ have approximately half the area of Lake Macquarie at 42 $\mathrm{km}^{2}$ and $38 \mathrm{~km}^{2}$ respectively (Fig. 1). Lake Macquarie and St Georges Basin are classified as "wavedominated" estuaries which rely predominantly on wind induced waves for water transport and are characterised by narrow entrances that restrict marine flushing via tidal cycles (NATIONAL LAND \& WATER RESOURCES AUDIT (NLWRA), 2009). In contrast, Botany Bay is classified as a "tidedominated" estuary being exposed to oceanic swells and having a wide entrance which promotes efficient marine flushing through tidal cycles and wave action. Lake Macquarie is a source of cooling water for three power stations located adjacent to the lake and has been extensively modified by urban development. Botany Bay has also been extensively modified by industrial, urban and port developments and includes shipping terminals, airport runways and large break walls (ALBANI, 2008). In comparison, the St Georges Basin system is relatively undeveloped with $80 \%$ of the area adjacent to the estuary consisting of native vegetation (NLWRA, 2009). The salinity of Botany Bay and St Georges Basin ranges from 30 - 35 parts 
per thousand (ppt) whereas the salinity of Lake Macquarie ranges from 28 - 41 ppt. The temperature of Botany Bay and St Georges Basin ranges from 13 -
28 degrees whereas the temperature of Lake Macquarie ranges from $10-28$ degrees annually (NLWRA, 2009).

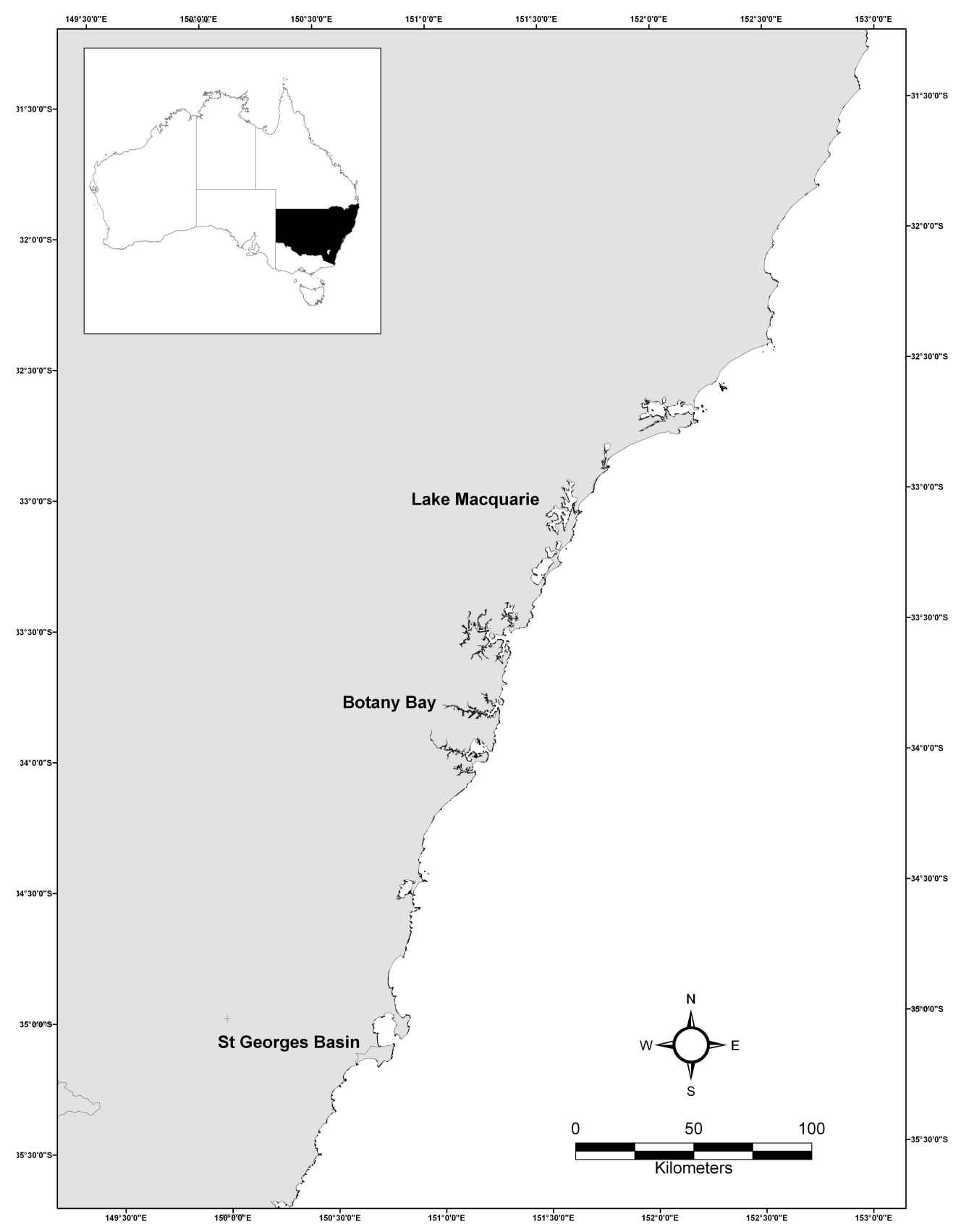

Fig. 1. Location of artificial reef sites (Lake Macquarie, Botany Bay St, Georges Basin). 


\section{Reef Deployment}

The subtidal artificial reef systems in each estuary consisted of 180 individual modules (Mini Bay Reef Ball ${ }^{\circledR}$ ) divided into six separate artificial reefs. The Mini Bay Reef Balls ${ }^{\circledR}$ are approximately 70 centimeters $(\mathrm{cm})$ tall with a base diameter of approximately $100 \mathrm{~cm}$ and were arranged in a single layer with a distance of approximately 50 to $100 \mathrm{~cm}$ between each module. Each of the reefs was assigned a designator to identify its site, Lake Macquarie (LM), Botany Bay (BB) and St Georges Basin (SGB) and reef type AR1- AR6. The Lake Macquarie reefs were deployed in December 2005 over an area of approximately $3 \mathrm{~km} 2$ approximately $200 \mathrm{~m}$ apart. The six reefs deployed at the St Georges Basin site were deployed in February 2007 over a larger area $(5 \mathrm{~km} 2)$ approximately $400 \mathrm{~m}$ apart. Lake Macquarie and St Georges Basin reefs were all deployed on sandy bottoms along the $6 \mathrm{~m}$ depth contour at least $3 \mathrm{~km}$ from naturally occurring reef. The Botany Bay reefs deployed in June 2006 were spread over approximately $4 \mathrm{~km} 2$ with the distance between reefs ranging from $200-500 \mathrm{~m}$. Reefs BBAR5 and BBAR6 were deployed relatively close to the entrance $(<2 \mathrm{~km})$ at a depth of $10 \mathrm{~m}$ and adjacent to areas of naturally occurring reefs. Reefs BBAR1-BBAR4 were all deployed in relatively protected embayments at a depth of approximately $6 \mathrm{~m}$. Only BBAR3 - BBAR6 were included in this study due to the rapid accumulation of sediment and subsequent burial of BBAR1 and BBAR2.

\section{Data Collection and Analysis}

Each of the artificial reefs at each site was sampled every spring and autumn over a two-year period post deployment. Six random replicate photoquadrats representing approximately 0.5 square metres $\left(\mathrm{m}^{2}\right)$ of the reef's surface were taken at each reef in each estuary by SCUBA divers using an Olympus C8080 (8 megapixel) digital camera fitted with a waterproof housing (BOHNSACK, 1979). All sides of the reef modules were photographed excluding the interior of the reef modules. The photo-quadrats were analysed in the laboratory using the image analysis computer program Coral Point Count (KOHLER; GILL, 2006). One hundred random points were superimposed over each photo-quadrat image and each point was assigned to the taxon located beneath it (BOHNSACK, 1979; CLYNICK et al., 2007; WALKER et al., 2007). Material was collected and preserved directly from the reef or images were enhanced and forwarded to experts for positive identification when necessary. Samples were identified to the lowest possible taxonomic level and algae were further grouped as FTA or foliose algae (FOWLER-
WALKER; CONNELL, 2002). Mean percentage cover information derived from replicate reefs was analysed to detect differences in the structure of communities between estuaries and between replicate artificial reefs within each estuary.

Non-parametric multivariate analysis was used to identify patterns in the assemblage structure using PRIMER 6 software (CLARKE; WARWICK, 1994). A Bray-Curtis similarity matrix was calculated using standardised, square-root transformed percentage cover data. Ordination of the data was then carried out using non-metric multidimensional scaling (nMDS) plots. One way analysis of similarities (ANOSIM) was used to investigate differences in community patterns between estuaries and among artificial reefs within each estuary. The contribution of each taxon to average dissimilarity between estuaries and reefs within estuaries was determined using the SIMPER routine in PRIMER-E (CLARKE, 1993). Similarity percentages (SIMPER) were used to examine which taxa contributed to any observed differences in assemblage composition by identifying those with a ratio of similarity to standard deviation of greater than 1.0. The ratio of the average similarity and standard deviation (Sim/SD) is given as a measure of how consistently each taxon contributes to similarities within groups. Taxa displaying a high average similarity/standard deviation ratio and a high contribution can be considered good discriminating species (CLARKE; WARWICK, 1994).

The relationship between time (days postdeployment) and species abundance (\% cover) was further investigated using CHAID analysis (Chi Squared Automatic Interaction Detector) (KASS, 1980). CHAID is an exploratory method used to study the relationship between a target variable, in this case days post-deployment and a series of predictor variables (percentage cover of each taxon). The analysis creates a non-binary tree in which Chi-square tests (or in the case of a continuous target variable $\mathrm{F}$ tests) determine the optimum splitting resulting in the assignment of statistically significant subsets or nodes in order to create a classification tree. The significance level ( $\alpha$ ) for both the splitting of nodes and the merging of data was set at 0.05 . Bonferroni adjustment was used to correct alpha levels for multiple comparisons. Tree growth was limited to a maximum depth (number of levels below the root node) of four.

\section{Result}

Results are based on the analysis of 1691 images collected over 52 sample days. A total of 17 taxa were recorded with the majority (16 taxa) found on the Botany Bay reefs. In contrast, four taxa were recorded on Lake Macquarie reefs and nine taxa on St 
Georges Basin reefs (Table 1). Multi dimensional scaling analysis identified significant differences in percentage cover between estuaries ( $R=0.301$, $\mathrm{P}=0.001)$. There was no significant difference in assemblages between artificial reefs in Lake Macquarie or St Georges Basin. In contrast, analysis found significant differences in the percentage cover of taxa $(\mathrm{R}=0.329, \mathrm{P}<0.001)$ between artificial reef complexes in Botany Bay. SIMPER analysis of individual Botany Bay reefs (BBAR3-BBAR6) indicated an increase in the number of taxa contributing most to similarities within each reef (Sim/SD>1) indicating a shift from the dominance of filamentous turfing algae (FTA) at BBAR3 to the increase in growth of the algal species Ecklonia radiata and Delisea pulchra at the more exposed BBAR5 \& 6 (Table 2).

Table 1. Mean percentage cover and standard error (SE) for each taxon at each location.

\begin{tabular}{|c|c|c|c|c|c|c|c|}
\hline \multirow[b]{2}{*}{ Taxa } & & \multicolumn{2}{|c|}{ Lake Macquarie } & \multicolumn{2}{|c|}{ Botany Bay St } & \multicolumn{2}{|c|}{ Georges Basin } \\
\hline & & $\%$ Cover & SE & $\%$ Cover & SE & $\%$ Cover & SE \\
\hline Filamentous turfing algae (FTA) & 77.7 & 8.4 & 41.3 & 3.7 & 53.5 & 4.8 & \\
\hline Foliose algae(unidentified) & & & & 12.7 & 3.1 & 0.02 & $\sim$ \\
\hline Polychaeta & 0.8 & 0.02 & 10.7 & 2.2 & 2.3 & 0.6 & \\
\hline Echinoder ms & & 0.3 & 0.05 & 0.1 & $\sim$ & & \\
\hline Bryozoans & & & 2.9 & 0.5 & & & \\
\hline Ascidians & & & & 2.3 & 0.3 & 0.4 & $\sim$ \\
\hline Sponges & & 0.2 & 0.06 & 0.1 & $\sim$ & & \\
\hline Molluscs & & 0.2 & 0.05 & & & & \\
\hline Anthozoa & & 0.01 & $\sim$ & & & & \\
\hline Barnacles & & 2.7 & 0.7 & 44.1 & 3.4 & & \\
\hline Barnacles_with polychaeta & & & & 30.5 & 4 & & \\
\hline Barnacles with sponge & & & 5 & 1 & & & \\
\hline Barnacles with FTA & & & & 3.7 & 1.4 & & \\
\hline Bare space & & & 4.6 & 1.5 & & & \\
\hline Spyridia filamentosa & & 22.4 & 2.2 & & & & \\
\hline Delisea pulchra & & & & 14.7 & 1.9 & & \\
\hline Amphiroa & & & & 1.6 & 0.3 & & \\
\hline Peyssonnelia capensis & & & 1.2 & 0.3 & & & \\
\hline Ecklonia radiata & & & & 9.2 & 1.2 & & \\
\hline Zonaria & & & & 0.4 & $\sim$ & & \\
\hline Caulerpa taxifolia & & & & 0.02 & $\sim$ & & \\
\hline
\end{tabular}

Table 2. Species contributing to epibenthic assemblages associated with reef complexes in Botany Bay (BBAR3-BBAR6) (SIMPER analysis). Average abundance, expressed as percentage cover of associated taxa. Sim/SD, similarity/standard deviation.

\begin{tabular}{|c|c|c|c|c|c|}
\hline Site & Species & Av.Abund & Av.Sim & Sim/SD & Contrib\% \\
\hline \multirow[t]{3}{*}{ BBAR3 } & Foliose algae & 6.38 & 29.79 & 1.16 & 57.76 \\
\hline & FTA & 4.92 & 16.39 & 0.76 & 31.77 \\
\hline & E. radiata & 0.68 & 1.34 & 0.35 & 2.6 \\
\hline \multirow[t]{4}{*}{ BBAR4 } & FTA & 7.28 & 34.53 & 1.48 & 61.13 \\
\hline & Bryozoans & 1.85 & 7.35 & 1.58 & 13.01 \\
\hline & D. pulchra & 1.77 & 6.07 & 0.9 & 10.74 \\
\hline & Polychaeta & 2.63 & 4.78 & 0.44 & 8.47 \\
\hline \multirow[t]{7}{*}{ BBAR5 } & FTA & 4.76 & 13.6 & 0.96 & 26.08 \\
\hline & E. radiata & 3.66 & 11.5 & 1.81 & 22.04 \\
\hline & D. pulchra & 2.66 & 8.05 & 1.59 & 15.43 \\
\hline & Polychaeta & 3 & 5.4 & 0.49 & 10.35 \\
\hline & Amphiroa & 1.84 & 4.82 & 1.05 & 9.24 \\
\hline & P. capensis & 1.44 & 3.54 & 1.02 & 6.79 \\
\hline & Bryozoans & 1.14 & 2.04 & 0.78 & 3.91 \\
\hline \multirow[t]{5}{*}{ BBAR6 } & D. pulchra & 5.38 & 19.95 & 2.04 & 34.32 \\
\hline & FTA & 4.52 & 14.93 & 1.42 & 25.69 \\
\hline & E. radiata & 2.96 & 9.29 & 1.47 & 15.98 \\
\hline & Bryozoans & 1.62 & 4.58 & 1.25 & 7.88 \\
\hline & Barnacles & 1.63 & 3.82 & 0.92 & 6.58 \\
\hline
\end{tabular}


Recruitment of taxa identified on each of the artificial reef systems was relatively rapid with the majority of taxa (94\%) identified within the first year post-deployment (Fig. 2). The Lake Macquarie reefs were characterised by low diversity with two taxa (FTA and algae Spyridia filamentosa) accounting for $78 \%$ and $22 \%$ respectively of the total mean percentage cover. Percentage cover reflected taxon frequency with FTA identified in $92 \%$ of the 96 samples, S. filamentosa in $36 \%$ and polychaeta in 15 $\%$ of all Lake Macquarie samples. Filamentous turfing algae and barnacles dominated the reefs in St Georges Basin with a mean percentage cover of $53.5 \%$ and 44 $\%$ respectively (Table 1 ). The most dominant taxon in Botany Bay was FTA with an average percentage cover for the entire study period of $41.3 \%$ followed by $D$. pulchra $(14.7 \%)$, foliose algae (unidentified foliose algae species) $(12.7 \%)$, polychaeta $(10.7 \%)$ and $E$. radiata $(9.2 \%)$. The most frequent taxon in Botany Bay was D. pulchra which was recorded on 84 $\%$ of all samples, followed by FTA $(77 \%)$, bryozoans $(69 \%)$ and $E$. radiata $(62 \%)$. Other taxa unique to the Botany Bay sites were ascidians, sponges, barnacles, bryozoans and the exotic algal pest species Caulerpa taxifolia.

Figures $3 \mathrm{a}, \mathrm{b} \& \mathrm{c}$ show the CHAID analysis results. In Figure 3a, the top box (ID=1) shows a total number of samples of $595(\mathrm{~N}=595)$ with an average number of days post deployment for the entire sample of 503 (Mean=503). Filamentous turfing algae were those chosen by the CHAID analysis as the best predictor for initially splitting the entire sample and therefore the CHAID tree splits into two nodes (ID $=2$ \& ID=3). Node ID 2 shows that only 130 samples $(\mathrm{N}=130)$ had an average percentage cover of less than or equal to $0 \%$ (which is represented above the box) and the average number of days post deployment for these samples was 677 (Mean=677) (ROKACH; MAIMON, 2008). The CHAID analysis then splits these samples further using $S$. filamentosa as the next best predictor. Spyridia filamentosa was recorded on 98 of the 130 samples as node ID 5 represents samples with an average percentage cover of more that $0 \%$. By continuing this process of interpretation, the CHAID analysis comparing reef age (days post-deployment) with percent coverage data for Lake Macquarie (Fig. 3a) identifies a significant reduction in the abundance of FTA (node ID 2 and 3) with an increase in reef age. An increase in the coverage of FTA was linked to the proportional coverage of polychaete species (node ID 6 \& 7). Only 49 of the samples with FTA recorded polychaetes, those that did not were then linked to the average percentage cover of $S$. filamentosa. Conversely, a reduction in the coverage of FTA with an increase in reef age was identified with variation in the coverage of $S$. filamentosa (node ID $4 \& 5$ ).

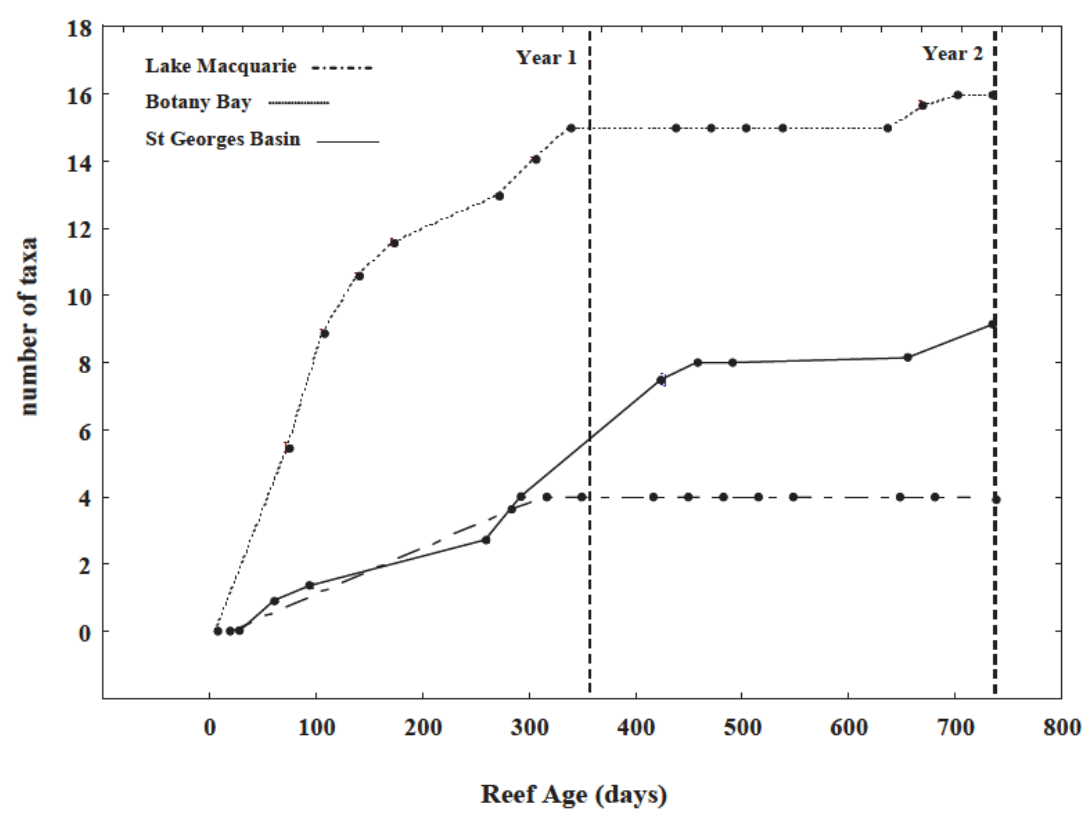

Fig. 2. Cumulative number of taxa with reef age (days post deployment) for artificial reef sites in Lake Macquarie, Botany Bay and St Georges Basin. 
(a) Lake Macquarie
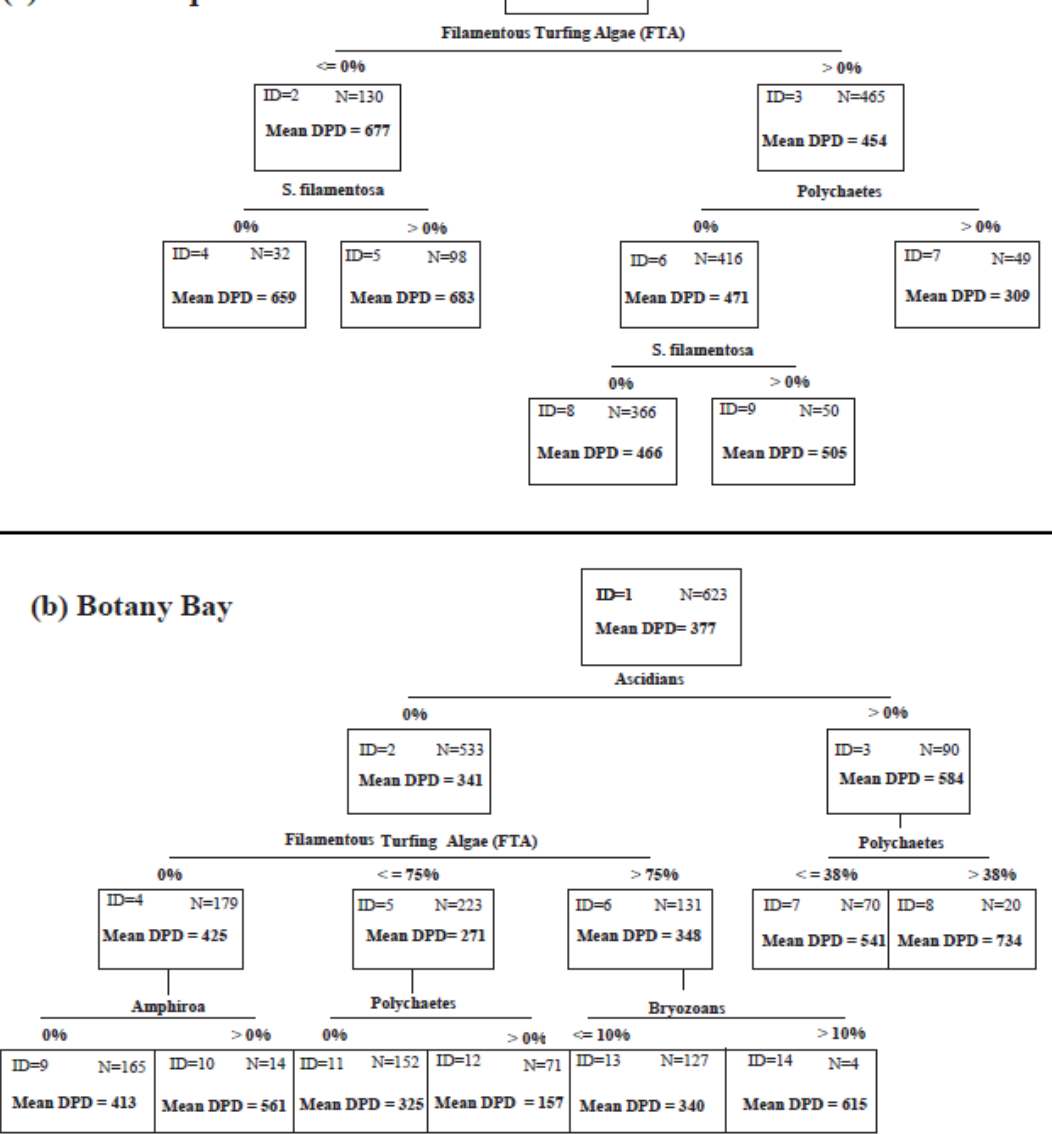

(c) St Georges Basin
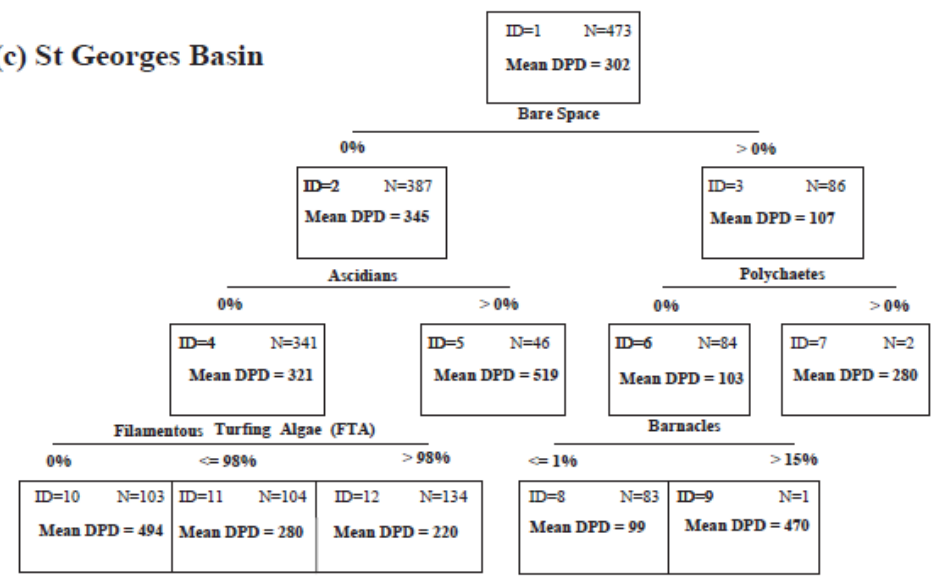

Fig. 3a, b and c. CHAID Classification indicating relationship between mean values of the target variable - days post deployment (DPD) and percentage cover of each taxon for (a) Lake Macquarie, (b) Botany Bay and (c) St Georges Basin. Each node provides identification number (ID) and summary statistics for the target variable. Mean DPD indicated in bold. Percentage differences for independent variables (taxa) are provided for each node. Significance level $(p)=0.05$. 
Analysis of percentage cover information for the Botany Bay site reflected the high level of diversity producing a fitted tree consisting of fourteen nodes (Fig. 3b). The initial split identified percentage cover of ascidians (node ID $2 \& 3$ ) as a first order factor. Zero coverage of ascidians was identified as a major factor $(\mathrm{N}=533)$ for reefs deployed on average for less than a year (341 days) with a greater coverage associated with reefs approaching two years (584 days) post-deployment. Increased percentage cover of ascidians was also associated with polychaete abundance (node ID $7 \& 8$ ) with a greater proportion of polychaetes $(>38 \%)$ associated with a mean reef age of 734 days decreasing $(<38 \%)$ on reefs with a mean age of 541 days. Low ascidian abundance was more closely associated with FTA (node ID 4, 5 \& 6) with percentage cover of FTA increasing (>75\%) with a mean reef age of 348 days whilst decreasing to less than $0 \%$ cover at 425 days post-deployment. In both Botany Bay and St Georges Basin, FTA cover was inversely proportional to the percentage cover of ascidians. Third order relationships (node ID 9 - 14) indicate an increase in the coverage of alga Amphiroa with decreases in abundance of FTA and an increase in the coverage of bryozoans (>10\%) associated with high abundance of FTA and relatively long periods post deployment ( $>615$ days).

St Georges Basin presents a more obvious pattern of succession (Fig. 3c) with the proportion of bare space (node ID $2 \& 3$ ) decreasing over time. A greater proportion of bare space is associated with the appearance of polychaetes and barnacles (node ID 7 \& 9) both increasing in percentage cover with increasing reef age. Barnacles with secondary cover (Table 1) were grouped as barnacles to avoid over representation during CHAID analysis. As observed in Botany Bay and Lake Macquarie the presence of FTA was associated with low ascidian cover (node ID 4) and mirrored the response observed at the other locations with the percentage cover decreasing with increasing reef age (node ID 10 - 12).

\section{Discussion}

The development of epibenthic communities plays an important part in the evaluation of artificial structures as fisheries enhancement initiatives where epibenthic communities are directly linked to the holding capacity and productivity of the artificial reef system. The results of this study therefore confirm that artificial reefs constructed from Reef Ball ${ }^{\circledR}$ modules can provide an effective substrate for epibenthic community colonisation in southeast Australian estuarine environments.

The composition of the substratum in terms of surface chemistry, toxicity and endurance, can affect the settlement and recruitment of benthic organisms (BAINE, 2001; SPIELER et al., 2001). This correlates to the artificial reefs performance and longterm resilience (SHENG, 2000), as unsuitable material can lead to breakage and dispersed debris, which may in turn damage the surrounding environment (BROCK; NORRIS, 1989; WALDICHUK, 1988). Preliminary results indicate that from the perspective of epibenthic community development, Reef Ball ${ }^{\circledR}$ modules are suitable structures for the construction of artificial reefs and may offer a viable alternative to the enhancement of the wide variety of non designspecific structures that occur within estuaries in southeast Australia.

A range of physical parameters are known to influence the settlement of benthic invertebrates on natural and artificial substrata including spatial orientation, structural complexity, substratum composition and texture (ANDERSON; UNDERWOOD, 1994; GLASBY, 1999; GLASBY; CONNELL, 2001). Various types of substratum have been deployed in order to study the settlement preferences of corals and other fouling organisms (SPIELER et al., 2001 and references therein) with some studies suggesting that the relief of an artificial reef may greatly influence species composition and abundance of both its benthic invertebrates (BAYNES; SZMANT, 1989; GLASBY; CONNELL, 2001) and fish (RILOV; BENAYAHU, 2000). The uniformity of the Reef Ball ${ }^{\circledR}$ modules used in this study however, negates the influence of these physical parameters and suggests that other factors were more important in influencing the divergent epibenthic communities recorded in Lake Macquarie, Botany Bay and St Georges Basin.

Explaining differences in assemblages among reefs and among estuaries however, is difficult due to the many factors that affect epibenthic settlement and growth. The low diversity recorded in Lake Macquarie and St Georges Basin and high diversity recorded in Botany Bay may be the result not only of the physical characteristics of the substratum, but also of the geomorphology of the estuaries including parameters such as aspect, depth, sedimentation load and water circulation which play a key role in influencing the community structure of artificial reefs (SHENG, 2000; SPIELER et al., 2001). Although all three locations are classified as estuaries, their divergent geomorphology was the most likely factor affecting the epibenthic communities recorded during this study. Lake Macquarie and St Georges Basin are classified as wave-dominated estuaries with narrow entrances and little tidal movement resulting in higher levels of turbidity. Conversely, Botany Bay is classified as a tide-dominated estuary with a large entrance, exposure to oceanic swells and efficient marine flushing which inhibits turbidity. Moreover, 
Lake Macquarie and St Georges Basin are essentially coastal lakes whereas Botany Bay is representative of a coastal bay.

Exposure of reefs to wave energy can influence fouling assemblage structure and recruitment by favoring canopy forming species such as E. radiata which are designed to withstand high levels of wave energy (KENNELLY; LARKUM, 1983; WERNBERG; THOMSEN, 2005; WERNBERG; CONNELL, 2008). This is reflected in the results as $E$. radiata was only recorded in Botany Bay. This characteristic alone however, would not exclude $E$. radiata from developing on the sheltered reefs in Lake Macquarie and St Georges Basin. Low levels of water movement encourage the accumulation of sediments which can cover larvae, inhibit growth and hinder filter feeding, therefore reducing the ability of propagules to colonise the assemblage (ABELSON; DENNY, 1997). The ability of filamentous turfing algae (FTA) to trap sediments however, enables them to thrive in environments with high sediment loads (CONNELL, 2003, 2005). Furthermore, FTA is commonly the most abundant taxon and a major contributor to primary production on newly deployed artificial structures (BAILEY-BROCK, 1989; COPERTINO et al., 2006; LOH; et al., 2006). Our results are in agreement with those of previous descriptive and experimental studies that document the dominance of FTA in subtidal areas subjected to high rates of sedimentation (AIROLDI, 1998; IRVING; CONNELL, 2002; GORGULA; CONNELL, 2004; BALATA; PIAZZI et al., 2005). The results of this study therefore, suggest that the accumulation of sediment on the reefs in Lake Macquarie and St Georges Basin may have hindered the settlement of species such as E. radiata and D. pulchra whilst allowing FTA to thrive in the turbid conditions. In contrast, the high levels of water movement in Botany Bay would have reduced the amount of sediment on the reefs and allowed a more diverse range of species to settle.

Artificial reefs designed for fishery enhancement are typically deployed on bottom types of low heterogeneity in order to increase production in otherwise barren areas (WHITE, 1990; LUKENS et al., 1997). The transport and settlement of epibiotic species is a result of passive propagule transport and active larval site selection with flow rates determining to a large extent how far these propagules and larvae will travel (DENNY, 1985; BUTLER, 1991; JUDGE; CRAIG, 1997; HURD, 2000; ENGLAND et al., 2008). The close proximity of the Botany Bay reefs to the ocean and the variety of structures (artificial and natural) provide an obvious source of propagules for colonisation of the artificial structures which may have directly contributed to the higher levels of diversity recorded in Botany Bay. In contrast, the low diversity of the Lake Macquarie and St Georges Basin reefs may have been influenced by their greater distance from natural reefs.

Epibiotic species associated with artificial reefs offer favorable habitats for fish species by providing structural complexity, a source of food and predator protection (BEHRENTS, 1987; CARR, 1989; SEAMAN JR; SPRAGUE1991; EKLUND, 1997; COLEMAN; CONNELL, 2001; BOAVENTURA et al., 2006; KROHLING et al., 2006) with some studies comparing artificial reefs with naturally occurring reefs frequently reporting higher abundance and diversity of benthic and demersal fish species on artificial reefs (RILOV; BENAYAHU, 2000; FABI et al., 2002; RILOV; BENAYAHU, 2002). A clear priority for the development of artificial reefs for recreational fishery enhancement therefore, is the understanding of the relationship between fouling communities and the associated fish assemblages.

The increase in local diversity within the tide-dominated Botany Bay reefs is consistent with the "intermediate disturbance hypothesis" (CONNELL, 1978) in which higher levels of diversity are maintained by the continual disturbance associated with these higher energy environments (CONNELL; KEOGH, 1985). Low water movement reduces the rate at which metabolic processes takes place therefore inhibiting growth whereas increased water motion facilitates metabolic processes therefore enhancing growth (DENNY, 1985; JUDGE; CRAIG, 1997). It is possible that the "intermediate disturbance hypothesis" influenced the epibenthic communities observed during the study and is reflected in the growth of few species in Lake Macquarie and St Georges Basin which experienced limited water movement and the development of large algal species (E. radiata, $D$. pulchra) in Botany Bay which experiences higher levels of water transfer and wave energy.

This study has provided us for the first time with a clear understanding of the type of epibenthic communities that colonise artificial reefs constructed from Reef $\mathrm{Ball}^{\circledR}$ modules in southeast Australian estuaries. Changes in epibenthic community structure between estuaries and among reef systems deployed at the Botany Bay site were most likely driven by variation in water movement, water quality and wave intensity. The majority of estuaries in southeastern Australia are low energy, wave-dominated estuaries. Additional deployments of artificial reefs in these areas will therefore result in the development of epibenthic communities characterised by low diversity similar to those of Lake Macquarie and St Georges Basin. Priorities for future work include ongoing monitoring of epibiotic communities associated with estuarine artificial reefs combined with an integrated fish monitoring program to better understand the 
longer-term relationship between epibiotic communities and fish assemblages in order to develop successful artificial reefs for recreational fishery enhancement.

\section{REFERENCES}

ABELSON, A. Hydrodynamic impediments to settlement of marine propagules, and adhesive-filament solutions. Limnol. Oceanogr. , v. 39, n. 1, p. 164-169, 1994.

ABELSON, A.; DENNY, M. Settlement of marine organisms in flow. A. Rev. Ecol. Syst., v. 28, p. 317-339, 1997.

ABURTO - OROPEZA, O.; BALART, E. F. Community structure of reef fish in several habitats of a rocky reef in the Gulf of California. Mar. Ecol., v. 22, n. 4, p. 283305, 2001.

AIROLDI, L. Roles of disturbance, sediment stress, and substratum retention on spatial dominance in algal turf. Ecology, v. 79, n. 8, p. 2759-2770, 1998.

ALBANI, A. Environmental assessment of Botany Bay: sediments, sediment geochemistry \& foraminifera. Parramatta: Sydney Metropolitan Catchment Management Authority, 2008.

ANDERSON, M. J.; UNDERWOOD, A. J. Effects of substratum on the recruitment and development of an intertidal estuarine fouling assemblage. J. expl mar. Biol. Ecol., v. 184, p. 217-236, 1994.

BAILEY-BROCK, J. H. Fouling community development on an artificial reef in Hawaiian waters. Bull. mar. Sci., v. 44, n. 2, p. 580-591, 1989.

BAINE, M. Artificial reefs: a review of their design, application, management and performance. Ocean Coast. Mgmt.., v. 44, n. 3-4, p. 241-259, 2001.

BALATA, D.; PIAZZI, L.; CECCHI, E.; CINELLI, F. Variability of Mediterranean coralligenous assemblages subject to local variation in sediment deposition. Mar. environ. Res., v. 60, n. 4, p. 403-421, 2005.

BAYNES, T. W.; SZMANT, A. M. Effect of current on the sessilembenthic community structure of an artificial reef. Bull. mar. Sci., v. 44, n. 2, p. 545-566, 1989.

BEHRENTS, K. C. The influence of shelter availability on recruitment and early juvenile survivorship of Lythrypnus dalli Gilbert (Pisces: Gobiidae). J. expl mar. Biol. Ecol., v. 107, n. 1, p. 45-59, 1987.

BOAVENTURA, D.; MOURA, A.; LEITAO, F.; CARVALHO, S.; CURDIA, J.; PEREIRA, P.; FONSECA, L.; SANTOS, M. N.; MONTEIRO, C. C. Macrobenthic colonisation of artificial reefs on the southern coast of Portugal (Ancao, Algarve). Hydrobiologia, v. 555, p. 335-343, 2006.

BOHNSACK, J. A. Photographic quantitative sampling of hard-bottom benthic communities. Bull. mar. Sci., v. 29 , n. 2, p. 242-252, 1979.

BRANDEN, K. L.; POLLARD, D. A.; REIMERS, H. A. A review of recent artificial reef developments in Australia. Bull. mar. Sci., v. 55, n. 2-3, p. 982-994, 1994.

BROCK, R. E., NORRIS, J. E. An analysis of the efficacy of four artificial reef designs in tropical waters. Bull. Mar. Sci. v44, p. 934-941 1989.

BRICKHILL, M. J.; LEE, S. Y.; CONNOLLY, R. M. Fishes associated with artificial reefs: attributing changes to attraction or production using novel approaches. J. Fish Biol., v. 67, p. 53-71, 2005.
BUTLER, A. J. Effect of patch size on communities of sessile invertebrates in Gulf St Vincent, South Australia. J. expl mar. Biol. Ecol., v. 153, n. 2, p. 255-280, 1991.

BUTLER, A. J.; CONNOLLY, R. M. Development and long term dynamics of a fouling assemblage of sessile marine invertebrates. Biofouling, v. 9, p. 187-209, 1996.

CARR, M. H. Effects of macroalgal assemblages on the recruitment of temperate zone reef fishes. J. expl mar. Biol. Ecol., v. 126, n. 1, p. 59-76, 1989.

CARR, M. H.; HIXON, M. A. Artificial reefs: The importance of comparisons with natural reefs. Fisheries, v. 22, n. 4, p. 28-33, 1997.

CHAPMAN, M. G.; CLYNICK, B. G. Experiments testing the use of waste material in estuaries as habitat for subtidal organisms. J. expl mar. Biol. Ecol., v. 338, n. 2, p. 164-178, 2006.

CLARKE, K. R. Non-parametric multivariate analyses of changes in community structure. Aust. Ecol., v. 18, n. 1, p. 117-143, 1993.

CLARKE, K. R.; WARWICK, R. M. Change in marine communities: an approach to statistical analysis and interpretation. UK: Natural Environment Research Council, 1994.

CLYNICK, B. G.; CHAPMAN, M. G.; UNDERWOOD, A. J. Effects of epibiota on assemblages of fish associated with urban structures. Mar. Ecol. Prog. Ser., v. 332, p. 201-210, 2007.

COLEMAN, M. A.; CONNELL, S. D. Weak effects of epibiota on the abundances of fishes associated with pier pilings in Sydney Harbour. Environ. Biol. Fishes, v. 61, p. 231-239, 2001.

CONNELL, J. H. Diversity in tropical rain forests and coral reefs. Science, v. 199, n. 4335, p. 1302, 1978.

CONNELL, J. H.; KEOGH, M. J. Disturbance and patch dynamics of subtidal marine animals on hard substrata. . In: PICKETT, S. T. A.; WHITE, P. S. (Ed.). The ecology of natural disturbance and patch dynamics. New York: Academic Press, 1985. p. 125-151.

CONNELL, S. D. The monopolization of understorey habitat by subtidal encrusting coralline algae: a test of the combined effects of canopy-mediated light and sedimentation. Mar. Biol., v. 142, n. 6, p. 1065-1071, 2003.

CONNELL, S. D. Assembly and maintenance of subtidal habitat heterogeneity: synergistic effects of light penetration and sedimentation. Mar. Ecol. Prog. Ser., v. 289, p. 53-61, 2005.

COPERTINO, M. S.; CHESHIRE, A.; WATLING, J. Photoinhibition and photoacclimation of turf algal communities on a temperate reef, after in situ transplantation experiments. J. Phycol., v. 42, n. 3, p. 580-592, 2006.

COUTIN, P. Artificial reefs: applications in Victoria from a literature review. Marine and Freshwater Resources Institute, 2001.

DENNY, M. W. Water motion. In: LITTLER, M. M.; LITTLER, D. S. (Ed.). Handbook of Phycological Methods. New York: Cambridge University Press, 1985. p. 7-32.

EDWARDS, R. A.; SMITH, S. D. A. Subtidal assemblages associated with a geotextile reef in south-east Queensland, Australia. Mar. Freshwat. Res., v. 56, n. 2, p. 133-142, 2005. 
EKLUND, A. M. The importance of post-settlement predation and reef resource limitation on the structure of reef fish assemblages. In: INTERNATIONAL CORAL REEF SYMPOSIUM, 8. Proceedings..., v. 2, p. 1139. 1142, 1997.

ENGLAND, P. R.; PHILLIPS, J.; WARING, J. R.; SYMONDS, G.; BABCOCK, R. Modelling waveinduced disturbance in highly biodiverse marine macroalgal communities: support for the intermediate disturbance hypothesis. Mar. Freshwat. Res., v. 59, p. 515-520, 2008

FABI, G.; GRATI, F.; LUCCHETTI, A.; TROVARELLI, L. Evolution of the fish assemblage around a gas platform in the northern Adriatic Sea. ICES J. mar. Sci., v. 59, n. suppl, p. S309-315, 2002.

FOWLER-WALKER, M. J.; CONNELL, S. D. Opposing states of subtidal habitat across temperate Australia: consistency and predictability in kelp canopy-benthic associations. Mar. Ecol. Prog. Ser., v. 240, p. 49-56, 2002.

GLASBY, T. M. Effects of shading on subtidal epibiotic assemblages. J. Exp. mar. Biol. Ecol., v. 234, n. 2, p. 275-290, 1999.

GLASBY, T. M.; CONNELL, S. D. Urban structures as marine habitats. Urban Struct. Mar. Habitats, v. 28, n. 7, p. 595-598, 1999.

GLASBY, T. M.; CONNELL, S. D. Orientation and position of substrata have large effects on epibiotic assemblages. Mar. Ecol. Prog. Ser., v. 214, p. 127-135, 2001.

GORGULA, S. K.; CONNELL, S. D. Expansive covers of turf-forming algae on human-dominated coast: the relative effects of increasing nutrient and sediment loads. Mar. Biol., v. 145, n. 3, p. 613-619, 2004.

HURD, C. L. Water motion, marine macroalgal physiology, and production. J. Phycol., v. 36, n. 3, p. 453-472, 2000.

IRVING, A. D.; CONNELL, S. D. Interactive effects of sedimentation and microtopography on the abundance of subtidal turf-forming algae. Phycologia, v. 41, p. 517 522, 2002.

JUDGE, M. L.; CRAIG, S. F. Positive flow dependence in the initial colonization of a fouling community: results from in situ water current manipulations. J. expl mar. Biol. Ecol., v. 210, n. 2, p. 209-222, 1997.

KASS, G. V. An exploratory technique for investigating large quantities of categorical data. J. Roy. Stat. Soc., Series C., v. 29, n. 2, p. 119-127, 1980.

KENNELLY, S. J.; LARKUM, A. W. D. A preliminary study of temporal variation in the colonization of subtidal algae in an Ecklonia radiata community. Aquat. Biol., v. 17, n. 3-4, p. 275-282, 1983.

KNOTT, N. A.; UNDERWOOD, A. J.; CHAPMAN, M. G.; GLASBY, T. M. Epibiota on vertical and on horizontal surfaces on natural reefs and on artificial structures. J. mar. biol. Assoc. U. K., v. 84, n. 6, p. 1117-1130, 2004.

KOHLER, K. E.; GILL, S. M. Coral Point Count with Excel extensions (CPCe): A Visual Basic program for the determination of coral and substrate coverage using random point count methodology. Comput. Geosci., v. 32, p. 1259-1269, 2006.

KROHLING, W.; BROTTO, D. S.; ZALMON, I. R. Functional role of fouling community on an artificial reef at the northern coast of Rio de Janeiro State, Brazil. Braz. J. Oceanogr., v. 54, n. 4, p. 183-191, 2006.
LOH, T. L.; TANZIL, J. T. I.; CHOU, L. M. Preliminary study of community development and scleractinian recruitment on fibreglass artificial reef units in the sedimented waters of Singapore. Aquat. Conserv. mar. Freshwat. Ecosystem., v. 16, n. 1, p. 61-76, 2006.

LUKENS, R. R.; BELL, M.; BUCHANAN, M.; CULBERTSON, J.; DODRILL, J.; KASPRZAK, R.; TATUM, W. Guidelines for marine artificial reef materials. U.S. Fish and Wildlife Service. Technical Coordinating Committee Gulf States Marine Fisheries Commission, 1997

MOURA, A.; BOAVENTURA, D.; CÚRDIA, J.; CARVALHO, S.; CANCELA DA FONSECA, L.; LEITÃO, F.; SANTOS, M.; MONTEIRO, C. Effect of depth and reef structure on early macrobenthic communities of the Algarve artificial reefs (southern Portugal). Hydrobiologia, v. 580, n. 1, p. 173-180, 2007.

NLWRA - NATIONAL LAND \& WATER RESOURCES AUDIT OzCoasts: Botany Bay. v. 2009. n. 1, Jun 2009.

PITCHER, T. J.; SEAMAN JR, W. Petrarchs Principle: how protected human-made reefs can help the reconstruction of fisheries and marine ecosystems. Fish and Fisheries., v. 1, n. 1, p. 73-81, 2000.

POLLARD, D. A. Artificial habitats for fisheries enhancements in the Australia region. Mar. Fish. Rev., v. 51, n. 4, p. 11-28, 1989.

POLLARD, D. A.; MATTHEWS, J. Experience in the construction and siting of artificial reefs and fish aggregation devices in Australian waters, with notes on and a bibliography of Australian studies. Bull. mar. Sci., v. 37, n. 1, p. 299-304, 1985.

REDMAN, R. A.; SZEDLMAYER, S. T. The effects of epibenthic communities on reef fishes in the northern Gulf of Mexico. Fish. Mngt. Ecol., v. 16, n. 5, p. 360367, 2009.

RILOV, G.; BENAYAHU, Y. Fish assemblage on natural versus vertical artificial reefs: the rehabilitation perspective. Mar. Biol., v. 136, n. 5, p. 931-942, 2000.

RILOV, G.; BENAYAHU, Y. Rehabilitation of coral reeffish communities: The importance of artificial-reef relief to recruitment rates. Bull. mar. Sci., v. 70, n. 1, p. 185197, 2002.

ROKACH, L.; MAIMON, O. Data mining with decision trees: theory and applications. World Scientific Pub Co., 2008.

RULE, M. J.; SMITH, S. D. A. Depth-associated patterns in the development of benthic assemblages on artificial substrata deployed on shallow, subtropical reefs. J. expl Mar. Biol. Ecol., v. 345, n. 1, 2007.

SEAMAN JR, W. Artificial reef evaluation with application to natural marine habitats. Boca Raton, Fla.: Taylor \& Francis, 2000.

SEAMAN, JR, W.; JENSEN, A. C. Purposes and practices of artificial reef evaluation. In: SEAMAN JR, W.; (Ed.). Artificial reef evaluation with natural marine habitat. Boca Raton, Fla: CRC Press, 2000. p. 1.

SEAMAN JR, W.; SPRAGUE, L. M. Artificial habitats for marine and freshwater fisheries. San Diego: Academic Press, 1991

SEAMAN, JR, W.; BUCKLEY, R. M.; POLOVINA, J. J. Advances in knowledge and priorities for research, technology and management related to artificial aquatic habitats. Bull. Mar. Sci., v. 44, n. 2, p. 527-532, 1989. 
SHENG, Y. P.Physical characteristics and engineering at reef sites. In: SEAMAN JR, W.; (Ed.). Artificial reef evaluation with natural marine habitat. Boca Raton, Fla: CRC Press, 2000., p.51 2000.

SHERMAN, R. L.; GILLIAM, D. S.; SPIELER, R. E. A preliminary examination of depth associated spatial variation in fish assemblages on small artificial reefs. J. appl. Ichthy., v. 15, n. 3, p. 116-121, 1999.

SPIELER, R. E.; GILLIAM, D.S.; SHERMAN, R. L.; Artificial substrate and coral reef restoration: What do we need to know to know what we need. Bull. Mar. Sci. v 69, p. 1013-1030. 2001

SU, D. T.; LUI, T. L.; OU, C. H. Numerical investigation into effects of seabed topography on flows in and around artificial reefs. Fish. Sci., v. 74, n. 2, p. 236-254, 2008.

SUTTON, S. G.; BUSHNELL, S. L. Socio-economic aspects of artificial reefs: Considerations for the Great Barrier Reef Marine Park. Ocean Coast. Mgmt., v. 50, p. 829846, 2007.

SVANE, I.; PETERSEN, J. K. On the problems of epibioses, fouling and artificial reefs, a review. Mar. Ecol., v. 22 n. 3, p. 169-188, 2001.

WALDICHUK, M. Incineration at sea and artificial reefs: Options for marine waste disposal MAR. POLLUT. BULL.. v 19 n 11, p 11 -22 1988.
WALKER, S. J.; SCHLACHER, T. A.; SCHLACHERHOENLINGER, M. A. Spatial heterogeneity of epibenthos on artificial reefs: fouling communities in the early stages of colonization on an east Australian shipwreck. Mar. Ecol., v. 28, n. 4, p. 435-445, 2007.

WERNBERG, T.; CONNELL, S. D. Physical disturbance and subtidal habitat structure on open rocky coasts: Effects of wave exposure, extent and intensity. J. Sea Res., v. 59, n. 4, p. 237-248, 2008.

WERNBERG, T.; THOMSEN, M. S. The effect of wave exposure on the morphology of Ecklonia radiata. Aquat. Bot., v. 83, n. 1, p. 61-70, 2005

WHITE, A. T.; MING, C. L.; DE SILVA, M. W. R. N.; GUARIN, F. Y. Artificial reefs for marine habitat enhancement. Manila: International Center for Living Aquatic Resources Management, 1990.

(Manuscript received 23 May 2010; revised 31 May 2011; accepted 15 June 2011) 